\title{
Analisis kandungan Timbal (Pb) dan Kadmium (Cd) dalam kangkung air (Ipomoea aquatica Forks.) di rawa yang dialiri limbah cair rumah tangga
}

\author{
Analysis of Lead $(\mathrm{Pb})$ and Cadmium $(\mathrm{Cd})$ in water spinach (Ipomoea aquatica Forks.) \\ in a swamp with domestic wastewater \\ Suraida $^{1, *}$, Boby Syefrinando ${ }^{1}$, Alfian $^{1}$, Fistoni $^{2}$ \\ ${ }^{1}$ Program Studi Tadris Biologi, Fakultas Tarbiyah dan Keguruan, UIN Sulthan Thaha Saifuddin Jambi, \\ Jl. Jambi-Ma Bulian KM 16, Muaro Jambi, 36361 \\ ${ }^{2}$ SMP Al Mukhtariyah Sarolangun, Dusun Bakti Desa Lubuk Resam, Kecamatan Nan Gadang, Kabupaten Sarolangun, \\ Provinsi Jambi
}

*Email: suraida@uinjambi.ac.id

Diterima 15 Februari $2021 \quad$ Disetujui 23 Agustus 2021

\section{INTISARI}

Penelitian ini bertujuan untuk menentukan kandungan timbal $(\mathrm{Pb})$ dan kadmium $(\mathrm{Cd})$ dalam tanaman kangkung air (Ipomoea aquatica Forks.) di rawa yang dialiri limbah cair rumah tangga. Jenis penelitian ini adalah penelitian observasional dilakukan dengan pendekatan deskriptif melalui uji logam berat di laboratorium. Hasil penelitian menunjukkan bagian tanaman yang mengakumulasi logam berat paling tinggi adalah bagian akar, lalu batang, sedangkan daun tidak terkandung logam. Organ akar mengandung logam $\mathrm{Pb}$ sebesar $0,0146 \mathrm{mg} / \mathrm{kg}$ dan logam $\mathrm{Cd}$ sebesar $0,0018 \mathrm{mg} / \mathrm{kg}$. Bagian organ batang mengandung timbal sebesar $0,0012 \mathrm{mg} / \mathrm{kg}$ dan logam Cd sebesar $0,000867 \mathrm{mg} / \mathrm{kg}$. Semuanya masih di bawah batas maksimum cemaran logam untuk bahan pangan sehingga masih aman untuk dikonsumsi masyarakat.

Kata kunci: $C d$, kangkung air, logam berat, $P b$, rawa

\begin{abstract}
This study aimed to determine the content of lead $(\mathrm{Pb})$ and cadmium $(\mathrm{Cd})$ in water spinach (Ipomoea aquatica Forks.) growing in swamps where household wastewater flows. This type of study is observational, carried out using a descriptive approach through heavy metal testing in the laboratory. The results showed that the parts of the plant that accumulated the most heavy metals were roots, followed by stems, while leaves did not contain metals. Root organs contained $0.0146 \mathrm{mg} / \mathrm{kg}$ of Pb and $0.0018 \mathrm{mg} / \mathrm{kg}$ of Cd metal. The stem organ section contains $0.0012 \mathrm{mg} / \mathrm{kg}$ of lead and $0.000867 \mathrm{mg} / \mathrm{kg}$ of Cd. All are still below the maximum limit of metal contamination for foodstuffs, and therefores still safe for public consumption.
\end{abstract}

Keywords: Cd, water spinach, heavy metal, Pb, swamps

\section{PENDAHULUAN}

Indonesia adalah tergolong Negara yang sedang berkembang, sehingga tidak dapat dihindari masih banyaknya masyarakat yang kurang sadar akan pentingnya menjaga dan melestarikan lingkungan hidup. Hal ini terlihat dengan pengolahan limbah rumah tangga yang 
belum optimal dan langsung dibuang ke lingkungan. Pengolahan dan tata caranya masih sangat rentan akan kesalahan.

Semakin meningkatnya suatu populasi dan kepadatan penduduk suatu wilayah, maka semakin tinggi pula aktivitas perluasan permukiman. Akibatnya adalah semakin tinggi pula aktivitas penduduk, salah satunya adalah meningkatnya aktivitas rumah tangga. Hal ini pula berdampak kepada meningkatnya volume limbah dalam bentuk apapun yang tentunya akan menimbulkan dampak negatif pada kelestarian lingkungan hidup.

Selain berdampak langsung pada lingkungan, limbah yang dihasilkan juga berdampak pada suatu organisme tertentu bila berkontak langsung pada limbah yang dihasilkan. Masyarakat masih banyak yang beranggapan bahwa membuang limbah cair rumah tangga ke lingkungan secara langsung tidak berdampak buruk pada kelestarian lingkungan.

Selain itu juga, akibat dari perluasan daerah permukiman maka semakin terbatas pula lahan pertanian yang ada. Ada banyak sekali jenis lahan pertanian baik itu di darat dan juga di air, salah satu pertanian di air adalah lahan pertanian yang memanfaatkan rawa sebagai lahan pertanian.

Rawa merupakan daerah yang sangat berpotensi terdampak paling besar, karena sebagian besar daerah permukiman di Indonesia terutama di Jambi masih memanfaatkan rawa sebagai tempat pembuangan limbah, terutama bagi limbah cair rumah tangga. Hal ini disebabkan karena tidak adanya perencanaan yang matang dari awal pada tahap pembangunan dan perluasan pemukiman, sehingga rawalah yang dimanfaatkan dalam pengolahan limbah cair. Selain rawa dimanfaatkan sebagai muara pengolahan limbah cair, rawa ini dimanfaatkan sebagai lahan pertanian terutama tanaman yang mampu tumbuh dan beradaptasi pada lingkungan berair.

Salah satu tanaman air yang dibudidayakan atau dikembangkan dalam pemanfaatan rawa sebagai lahan pertanian adalah tanaman kangkung air di mana tanaman ini mampu tumbuh dengan kondisi tersebut. Tanaman kangkung air sangat toleran terhadap limbah cair, maka tanaman ini sangat banyak dimanfaatkan sebagai fitoremidiasi suatu lingkungan yang tercemar, salah satu jenis limbah yang dapat difitoremidiasi adalah jenis limbah logam berat yaitu timbal $(\mathrm{Pb})$ dan kadmium (Cd). Apabila tanaman kangkung air terakumulasi logam berat, dikonsumsi oleh manusia akan bersifat sangat toksik.

Limbah cair rumah tangga dibuang ke lingkungan melalui parit atau selokan dan muaranya adalah rawa. Rawa ini mampu menampung sebagian besar limbah rumah tangga yang dihasilkan perumahan, selain itu rawa ini dimanfaatkan juga sebagai penampungan air hujan. Rawa yang dialiri limbah cair rumah tangga ini terdapat di Perumahan Nasional Aurduri Provinsi Jambi. Rawa ini juga digunakan sebagai lahan pertanian kangkung air. Tanaman kangkung air ini dikonsumsi oleh beberapa individu yang menetap di sekitar rawa tersebut, dan tanaman ini juga dimanfaatkan oleh petani sebagai tanaman hasil pertanian yang diperjualbelikan di pasar. Di lokasi perumahan terdapat aktivitas pembuangan limbah rumah tangga yang berasal dari aktivitas usaha las teralis, perkayuan pengecatan mebel, percetakan, bengkel dan variasi mobil dan motor.

Berdasarkan penelitian Mulyani et al. (2012) dan Suhud et al. (2012) menyatakan bahwa tanaman kangkung air mampu menyerap logam berat timbal $(\mathrm{Pb})$ dan kadmium $(\mathrm{Cd})$ sehingga apabila dikonsumsi oleh manusia akan berdampak buruk bagi kesehatan khususnya pada bagian akar dan batang. Penelitian Liong et al. (2009) menunjukkan kangkung darat merupakan tanaman hiperakumulator terhadap $\mathrm{Cd}$. Berdasarkan uraian di atas, peneliti sangat tertarik mengangkat dan meneliti permasalahan ini, sehingga penelitian ini bertujuan untuk mengetahui ada tidaknya kandungan logam berat di rawa yang dialiri limbah cair rumah tangga, besar akumulasi logam berat timbal $(\mathrm{Pb})$ dan kadmium (Cd) pada tanaman kangkung air (Ipomoea aquatica Forks.). 


\section{MATERI DAN METODE}

\section{Tempat dan waktu penelitian}

Sampel tanaman kangkung air diambil di rawa/lahan pertanian kangkung Perumahan Nasional Aurduri 1 (satu), Kelurahan Penyengat Rendah, Kecamatan Telanaipura, Kota Jambi. Pengambilan sampel dilakukan pada waktu pagi hari \pm 07.00 WIB. Lokasi preparasi sampel di rumah peneliti di Jl. Ir. H. Juanda No.78, RT 22, Kelurahan Simpang III Sipin, Kecamatan Kotabaru, Kota Jambi. Pengujian logam berat dilakukan di Balai Laboratorium Kesehatan Jambi pada bulan Agustus-September 2019.

\section{Bahan dan alat}

Alat-alat yang digunakan antara lain: botol, tabung reaksi, cawan petri, pipet filter, bunsen, gelas ukur, tabung erlenmeyer, bejana, vial, kapas, spatula, tabung durham, oven, mortar dan alu, kertas label, plastik kaca, dirigen 2 lt, kertas tissue, kertas saring Whatman No.41, pH meter, termometer air raksa, neraca analitik, timbangan digital, microwave dan spektrofotometer serapan atom (AAS). Bahan yang digunakan adalah sampel penelitian berupa tanaman kangkung air (akar, batang, dan daun) yang berumur \pm 3 minggu ( \pm 21 hari) siap panen, air rawa dan air selokan. Bahan kimia berupa akuades, $\mathrm{HNO}_{3}$ pekat larutan $\mathrm{Pb}$ dan $\mathrm{Cd}$ standar.

\section{Metode}

Jenis penelitian ini merupakan penelitian observasional yang dilakukan melalui pedekatan secara deskriptif yaitu melalui uji logam berat di laboratorium.

Pengambilan sampel tanaman kangkung air (akar, batang dan daun) dilakukan di 3 kanal yang terkontak langsung dengan air limbah rumah tangga perumahan yang dilakukan sebanyak 3 kali ulangan. Sebelum melakukan pengambilan sampel peneliti menyiapkan dulu tempat sampel yang akan diujikan yaitu berupa kertas plastik kaca dan jerigen kapasitas 2 L yang terlebih dahulu telah disterilkan agar tanaman tidak menyerap bahan lain selain bahan-bahan atau unsur-unsur yang terdapat di rawa Perumahan Nasional Aurduri 1.

Prosedur pengambilan sampel di lapangan adalah sebagai berikut: sampel tanaman kangkung air dibersihkan, dipotong dan dipisahkan antara bagian akar, batang dan daun, dimasukkan ke dalam plastik kaca dan ditambahkan akuades secukupnya, sedangkan sampel air rawa dan air selokan dimasukkan ke dalam jerigen $2 \mathrm{~L}$, lalu dibawa ke laboratorium untuk diuji.

Preparasi sampel adalah sebagai berikut: bagian tanaman sebanyak $5 \mathrm{~g}$ dihancurkan dengan mortar dan alu, ditambahkan 10 mL HNO3 60\% lalu selama 20 menit dipanaskan pada suhu $90^{\circ} \mathrm{C}$, kemudian dinaikkan suhunya selama 1 jam menjadi $150^{\circ} \mathrm{C}$. Sampel lalu didinginkan, disaring dan ditambahkan akuades hingga volume $25 \mathrm{~mL}$. Kemudian sampel dikeringkan hingga suhu $105^{\circ}$ C dalam oven lalu ditimbang dalam krusibel dengan waktu 2 jam hingga diperoleh bobot konstan. Selanjutnya sampel dimasukkan dalam oven dikeringkan dengan waktu 36-48 jam pada suhu $105^{\circ} \mathrm{C}$ hingga diperoleh bobot konstan. Proses pengeringan ini dilakukan terus hingga diperoleh bobot konstan.

Destruksi sampel dilakukan dengan tahapan sebagai berikut : sampel tanaman kangkung air hasil preparasi pada prosedur sebelumnya sebanyak $2 \mathrm{~g}$ ditimbang menggunakan timbangan analitik, lalu ditambahkan $12 \mathrm{~mL}$ larutan $\mathrm{HNO}_{3}$ pekat dan diaduk perlahan, kemudian dimasukkan ke dalam pelindung merk HTC (High Tech Corporation) ditutup dan dikencangkan, dimasukkan ke dalam microwave, lalu disambungkan dengan sensor suhu, alat dinyalakan dengan suhu $180^{\circ} \mathrm{C}$ selama 25 menit dengan kekuatan 1000 watt. Setelah proses destruksi selesai, bejana dikeluarkan dan didinginkan sampai suhu kamar, kemudian bejana dibuka, larutan hasil destruksi dimasukkan ke dalam labu ukur $10 \mathrm{~mL}$ dan diencerkan dengan aqua demineralisata sampai garis batas, larutan kemudian disaring dengan kertas saring Whatman No. 41, lalu ditampung di dalam vial dan selanjutnya dianalisis menggunakan spektrofotometer serapan atom (AAS). 


\section{HASIL}

\section{Kandungan Logam Timbal (Pb)}

Berdasarkan hasil uji laboratorium pada tanaman kangkung air didapatkan data seperti yang ditampilkan pada Tabel 1.

Pada Tabel 1 didapatkan data bahwa analisis kandungan logam timbal $(\mathrm{Pb})$ di daun sebanyak tiga kali ulangan hasilnya adalah 0 (nol) artinya tidak didapatkan sama sekali kandungan logam timbal $(\mathrm{Pb})$. Organ batang didapatkan rerata kandungan logam timbal $(\mathrm{Pb})$ sebesar 0,0012 $\mathrm{mg} / \mathrm{kg}$ dan di akar didapatkan sebesar 0,0146 $\mathrm{mg} / \mathrm{kg}$. Kedua bagian organ batang dan akar tersebut yang terkandung logam timbal $(\mathrm{Pb})$ masih di bawah ambang batas maksimum cemaran logam untuk bahan pangan untuk kategori sayur yaitu $<0,20 \mathrm{mg} / \mathrm{kg}$ berdasarkan Peraturan Badan Pengawas Obat dan Makanan No.5 Th. 2018.

Tabel 1. Hasil Uji Laboratorium Kandungan Timbal (Pb) Pada Kangkung Air

\begin{tabular}{|c|c|c|c|c|c|c|c|}
\hline \multirow[t]{2}{*}{ No } & \multirow[t]{2}{*}{$\begin{array}{c}\text { Organ } \\
\text { Tanaman }\end{array}$} & \multicolumn{3}{|c|}{$\begin{array}{c}{[\mathrm{Pb}] \mathrm{mg} / \mathrm{kg}} \\
\text { Ulangan }\end{array}$} & \multirow[t]{2}{*}{$\begin{array}{c}\text { Rerata } \\
\mathrm{mg} / \mathrm{kg}\end{array}$} & \multirow[t]{2}{*}{ Spesifikasi Metode } & \multirow[t]{2}{*}{$\begin{array}{c}\text { Batas Maks } \\
\text { mg/kg }\end{array}$} \\
\hline & & 1 & 2 & 3 & & & \\
\hline 1 & Daun & 0 & 0 & 0 & 0 & \multirow{3}{*}{$\begin{array}{c}\text { APHA (3111B) } \\
2012\end{array}$} & $<0,20$ \\
\hline 2 & Batang & 0 & 0,0036 & 0 & 0,0012 & & $<0,20$ \\
\hline 3 & Akar & 0,0079 & 0,016 & 0,0222 & 0,0146 & & $<0,20$ \\
\hline
\end{tabular}

\section{Kandungan Logam Kadmium (Cd)}

Berdasarkan hasil uji laboratorium pada tanaman kangkung air didapatkan hasil data tercantum pada Tabel 2.

Berdasarkan hasil analisis uji laboratorium, kandungan logam kadmium $(\mathrm{Cd})$ dalam tanaman kangkung air di rawa yang dialiri limbah cair rumah tangga diperoleh data bahwa pada organ daun tidak ditemukan logam kadmium dengan nilai 0 (nol) $\mathrm{mg} / \mathrm{kg}$. Organ batang ditemukan kandungan kadmium (Cd) sebanyak 3 (tiga) kali ulangan dengan nilai rerata $0,000867 \mathrm{mg} / \mathrm{kg}$ dan akar nilainya $0,0018 \mathrm{mg} / \mathrm{kg}$. Kandungan logam kadmium (Cd) yang teridentifikasi hadir di kedua bagian organ batang dan akar masih di bawah ambang batas maksimum cemaran logam berat untuk pangan kategori sayuran yaitu sebesar 0,05 $\mathrm{mg} / \mathrm{kg}$ menurut Peraturan Badan Pengawas Obat dan Makanan No.5 Th. 2018.

Tabel 2. Hasil Uji Laboratorium Kandungan Kadmium (Cd) PadaKangkung Air

\begin{tabular}{|c|c|c|c|c|c|c|c|}
\hline \multirow[t]{2}{*}{ No } & \multirow[t]{2}{*}{$\begin{array}{c}\text { Organ } \\
\text { Tanaman }\end{array}$} & \multicolumn{3}{|c|}{$\begin{array}{c}{[\mathrm{Cd}] \mathrm{mg} / \mathrm{kg}} \\
\text { Ulangan }\end{array}$} & \multirow[t]{2}{*}{$\begin{array}{c}\text { Rerata } \\
\mathrm{mg} / \mathrm{kg}\end{array}$} & \multirow[t]{2}{*}{ Spesifikasi Metode } & \multirow[t]{2}{*}{$\begin{array}{c}\text { Batas Maks } \\
\text { mg/kg }\end{array}$} \\
\hline & & 1 & 2 & 3 & & & \\
\hline 1 & Daun & 0 & 0 & 0 & 0 & \multirow{3}{*}{$\begin{array}{c}\text { APHA (3111B) } \\
2012\end{array}$} & $<0,05$ \\
\hline 2 & Batang & 0,0004 & 0,001 & 0,0012 & 0,000867 & & $<0,05$ \\
\hline 3 & Akar & 0,0025 & 0,0021 & 0,0008 & 0,00146 & & $<0,05$ \\
\hline
\end{tabular}

\section{Parameter Fisik Air Rawa dan Air Limbah Cair Rumah Tangga}

Berikut ini adalah hasil analisis uji laboratorium air rawa yang ditanami kangkung air (Ipomoea aquatica Forks.) dan air limbah cair yang berasal dari rumah tangga. Berdasarkan hasil uji laboratorium didapatkan hasil bahwa air rawa memiliki nilai TDS (Total Dissolved Solid) lebih tinggi dibandingkan air limbah yaitu sebesar 399 mg/L dan TDS air limbah sebesar 307 mg/L.
Sedangkan untuk TSS (Total Suspended Solid) air limbah lebih tinggi yaitu sebesar $0,409 \mathrm{mg} / \mathrm{L}$ daripada air rawa yang ditanami kangkung air sebesar 0,395 mg/L (Tabel 3).

Air rawa dan air selokan memiliki nilai TDS masih di bawah baku mutu air untuk keperluan higiene sanitasi yaitu $1000 \mathrm{mg} / \mathrm{L}$ (Peraturan Menteri Kesehatan Republik Indonesia No.32 Th.2017). Padatan terlarut total (TDS) merupakan bahan terlarut dengan diameter $<10-6 \mu \mathrm{m}$ dan 
koloid dengan diameter 10-6 $\mu \mathrm{m}-10-3 \mu \mathrm{m}$ dan terdiri dari senyawa kimia dan bahan lain yang tidak tersaring pada kertas saring berdiameter
$0,45 \mu \mathrm{m}$ yang berasal dari kation dan anion yang digunakan dalam aktivitas rumahtangga (Suoth \& Nazir, 2016).

Tabel 3. Parameter Fisik Air Rawa dan Air Limbah Cair Rumah Tangga

\begin{tabular}{llllll}
\hline No & Parameter Fisik & Satuan/ Unit & Air Rawa & Air Limbah & Spesifikasi Metode \\
\hline 1 & TDS & $\mathrm{mg} / \mathrm{l}$ & 399 & 307 & SNI 3554: \\
2 & TSS & $\mathrm{mg} / \mathrm{l}$ & 0,395 & 0,409 & 2015 \\
\hline
\end{tabular}

Sedangkan untuk nilai TSS memiliki nilai di bawah baku mutu air limbah domestik yaitu sebesar $30 \mathrm{mg} / \mathrm{L}$ (Peraturan Menteri Lingkungan Hidup dan Kehutanan Republik Indonesia No. P.68/Menlhk/Setjen/Kum.1/8/2016). Padatan tersuspensi total (TSS) merupakan bahan tersuspensi dengan diameter $>1 \mu \mathrm{m}$ yang bertahan pada saringan milipore dengan diameter pori $0,45 \mu \mathrm{m}$ yang berasal dari lumpur dan pasir halus serta jasad-jasad renik. Dalam limbah rumahtangga TSS yang tinggi bisa berasal dari berbagai aktivitas seperti cuci, mandi dan bersihbersih rumah. TSS dapat meningkatkan nilai kekeruhan yang selanjutnya akan menghambat penetrasi cahaya matahari ke kolom air dan akhirnya berpengaruh terhadap proses fotosintesis di perairan (Suoth et al., 2016).

Melihat hasil TDS dan TSS dari air rawa dan air selokan yang di bawah kisaran ambang batas limbah menunjukkan bahwa biota masih mampu bertahan hidup di rawa tersebut terbukti dengan tumbuhnya tanaman kangkung air di area penelitian.

\section{PEMBAHASAN}

Berdasarkan hasil analisis terlihat bahwa kandungan logam berat timbal $(\mathrm{Pb})$ dan kadmium (Cd) dalam tanaman kangkung air (Ipomoea aquatica Forks.) adalah positif. Akan tetapi kandungannya masih di bawah baku mutu menurut aturan BPOM sebagai bahan pangan untuk kategori sayuran yang masih aman untuk dikonsumsi.

Logam berat timbal $(\mathrm{Pb})$ dan kadmium $(\mathrm{Cd})$ yang dikandung tanaman kangkung air paling tinggi diperoleh pada organ akar. Hal ini sesuai dengan teori akumulasi hara yang kontak dengan permukaan akar yaitu: diserap dalam larutan tanah secara difusi, diserap oleh aliran tanah secara pasif, dan dalam matriks tanah akar tumbuh ke posisi hara. Adanya konsentrasi yang tinggi dalam sel akar ini terjadi dalam waktu yang lama serta memiliki sifat akumulatif, satu arah, tidak dapat jenuh dan selektif (Lakitan, 2001).

Tanaman kangkung air (Ipomoea aquatica Forks.) termasuk tumbuhan hiperakumulator yang dapat menyerap logam berat dan memiliki biomassa berbeda-beda dilihat dari jenis logam tersebut. Batas hiperakumulator kadar logam kadmium setinggi 0,01\% (100 mg/kg), sedangkan batas hiperakumulator bagi timbal adalah $0,1 \%$ $(1000 \mathrm{mg} / \mathrm{kg}) \quad$ (Baker et al., 1999) dalam (Irhamni et al., 2017).

Menurut Irhamni et al.(2017) dijelaskan bahwa proses akumulasi logam berat dalam tumbuhan terjadi dalam 3 proses yaitu sebagai berikut: 1). Proses penyerapan oleh akar, 2). Ditransolaksikan oleh akar ke bagian lain tumbuhan, 3). Bagian sel tertentu akan melokalisasi logam tersebut. Oleh karena itu, tumbuhan akan menimbun logam dalam organ akar. Hal ini dilakukan agar metabolisme tumbuhan tidak terhambat dan tidak terjadi keracunan dalam sel. Pada dasarnya tumbuhan memiliki mekanisme detoksifikasi. Adanya protein dan glukosida yang merupakan molekul khelat dapat meningkatkan efisiensi pengangkutan logam. Kemudian logam diangkut ke batang dan daun, sedangkan eskresinya melalui transpirasi. Proses transpirasi terjadi di bagian stomata, kutikula dan lentisel. Stomata dan kutikula terdapat di bagian organ daun, 
sedangkan lentisel terdapat di batang. Hal ini karena organ daun paling banyak melakukan transpirasi jadi logam paling banyak dieksresikan oleh organ tersebut sehingga negatif mengandung logam. Organ batang paling sedikit mengandung logam dibanding akar karena bagian ekskresinya hanya berupa lentisel.

Terakumulasinya logam berat timbal $(\mathrm{Pb})$ dan kadmium (Cd) dalam tanaman kangkung air di rawa yang dialiri limbah cair rumah tangga di Perumahan Aur Duri 1 berasal dari kegiatankegiatan penduduk yang membuang limbah rumah tangga di perumahan tersebut. Setelah dilakukan observasi di lokasi penelitian didapatkan bahwa ada terdapat kegiatan-kegiatan yang memungkinkan terakumulasinya logam tersebut, misalnya kegiatan usaha las teralis, perkayuan pengecatan mebel, percetakan dan bengkel variasi mobil dan motor, dan pertanian.

Berdasarkan penelitian Eka \& Mukono (2017) menyatakan bahwa timbal berasal dari bahan pigmen warna yang terdapat dalam cat yang digunakan sebagai pada bengkel pengecatan mobil. Menurut Winder (2004) dalam (Eka \& Mukono, 2017), timbal (Pb) berasal dari aktivitas manusia meliputi bengkel, pengelasan, pabrik cat, perpipaan, industri peleburan, pengilangan timah hitam, pabrik aki dan baterai dan pabrik plastik.

Berdasarkan penelitian Sutrisno \& Kuntyastuti (2017), pencemaran logam kadmium berasal dari lahan pertanian yang telah tercemar dengan limbah industri, penggunaan pestisida serta pupuk kimia secara kontinyu ke lahan dan pembuangan sampah rumah tangga ke aliran sungai. Sampah rumah tangga meliputi serat sintetik, cat, plastik, baja, semen, minyak pelumas, dan keramik merupakan sumber logam kadmium yang tercemar pada perumahan. Hampir sebagian besar pengelolaan sampah di lokasi penelitian terlihat belum optimal karena terlihat sampah yang berserakan di selokan-selokan pengairan limbah rumah tangga.

\section{SIMPULAN}

Berdasarkan hasil dan pembahasan penelitian, maka kesimpulan dari penelitian ini adalah sebagai berikut: tanaman kangkung air (Ipomoea aquatica Forks.) yang ditanam di rawa yang dialiri limbah cair rumah tangga positif terdapat kandungan timbal $(\mathrm{Pb})$ dan kadmium $(\mathrm{Cd})$ pada bagian akar dan batang. Organ daun negatif mengandung logam berat. Organ akar mengandung logam $\mathrm{Pb}$ sebesar $0,0146 \mathrm{mg} / \mathrm{kg}$ dan logam Cd sebesar 0,0018 mg/kg. Organ batang mengandung timbal sebesar $0,0012 \mathrm{mg} / \mathrm{kg}$ dan logam Cd sebesar 0,000867 mg/kg. Semuanya masih di bawah batas maksimum cemaran logam untuk bahan pangan dalam kategori sayur, sehingga masih aman untuk dikonsumsi.

\section{UCAPAN TERIMA KASIH}

Peneliti mengucapkan terimakasih kepada UIN Sulthan Thaha Saifuddin Jambi yang telah memberi dana penelitian dengan judul "Analisis Kandungan Logam Timbal $(\mathrm{Pb})$ dan Kadmium (Cd) dalam Tanaman Kangkung Air (Ipomoea aquatica Forks.) di Rawa yang Dialiri Limbah Cair Rumah Tangga" dengan Surat Kontrak Kerja Penelitian Dasar Pengembangan Prodi dengan nomor SK : B-99/Un.15/LPPM/L.II.2/05/2019.

\section{KEPUSTAKAAN}

Eka H dan Mukono J. 2017. Hubungan kadar timbal dalam darah dengan hipertensi pekerja pengecatan mobil di Surabaya. Jurnal Kesehatan Lingkungan 9(1): 66-74.

Irhamni I, Pandia S, Purba E, Hasan W. 2017. Kajian Akumulator Beberapa Tumbuhan Air dalam Menyerap Logam Berat secara Fitoremediasi. Jurnal Serambi Engeneering, 1(2):344-351. https://doi.org/10.32672/jse.v1i2.498

Lakitan B. 2001. Dasar-Dasar Fisiologi Tumbuhan. Jakarta : Raja Grafindo Persada.

Liong S, Noor A, Taba P, Zubair H. 2009. Dinamika akumulasi Kadmium pada tanaman kangkung darat (Ipomoae reptans Poir ) Syarifuddin Liong. Jurnal Indonesia Chimica Acta 2(1): 1-7.

Mulyani S, Triani LIGA, Sujana AEN. 2012. Identifikasi cemaran logam $\mathrm{Pb}$ dan $\mathrm{Cd}$ pada kangkung yang ditanam di daerah kota 
Denpasar. Bumi Lestari Journal of Environment 12(2): 345-349.

Peraturan Menteri Lingkungan Hidup dan Kehutanan Republik Indonesia No. P.68/Menlhk/Setjen/Kum.1/8/2016 Tentang Baku Mutu Limbah Domestik. (n.d.). Menteri Lingkungan Hidup Dan Kehutanan, 1-13. Retrieved from http://neo.kemenperin.go.id/files/hukum/19 Permen LHK th 2016 No. P.63 Baku Mutu Air Limbah Domestik.pdf

Suhud I, Tiwow VMA, Hamzah B. 2012. Adsorpsi ion kadmium (II) dari larutannya menggunakan biomassa akar dan batang kangkung air (Ipomoea aquatica Forks). Jurnal Akademika Kimia, 1(4): 153-158.

Suoth EA, Nazir EN. 2016. Karakteristik air limbah rumah tangga pada salah satu perumahan menengah keatas di Tangerang Selatan. Jurnal Ecolab 10(2):80-88.

https://doi.org/10.20886/jklh.2016.10.2.80-88

Surat Peraturan Badan Pengawas Obat dan Makanan Republik Indonesia Nomor 5 Tahun 2018. 1-16.

Sutrisno dan Kuntyastuti H. 2017. Pengelolaan cemaran kadmium pada lahan pertanian di Indonesia. Buletin Palawija 13(1):83-91.

Tjokrokusumo K. 1995. Pengantar Konsep Teknologi Bersih: Khusus Pengelolaan dan Pengolahan Air. Retrieved from https://books.google.co.id/books?id=JWBfy gAACAAJ 